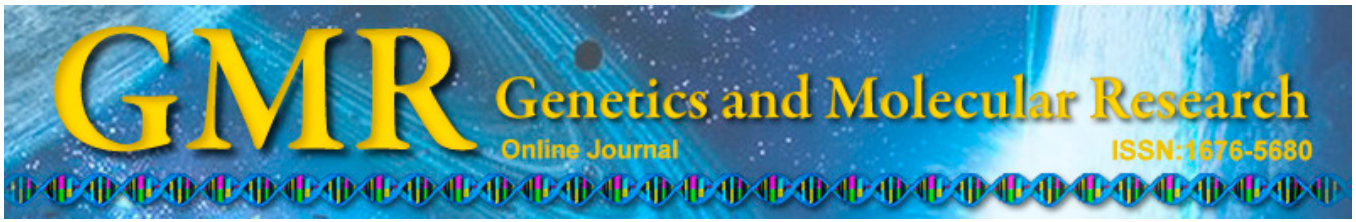

\title{
Expression of genes associated with the biosynthetic pathways of abscisic acid, gibberellin, and ethylene during the germination of lettuce seeds
}

\author{
A.C.S. Clemente ${ }^{1}$, R.M. Guimarães ${ }^{1}$, D.C. Martins ${ }^{2}$, L.A.A. Gomes ${ }^{1}$, \\ F. Caixeta ${ }^{1}$, R.G.E. Reis ${ }^{3}$ and S.D.V.F. Rosa ${ }^{4}$ \\ ${ }^{1}$ Laboratório Central de Sementes, Departamento de Agricultura, \\ Universidade Federal de Lavras, Lavras, MG, Brasil \\ ${ }^{2}$ Departamento de Agricultura, Universidade Federal de São João Del Rei, \\ Campus Sete Lagoas, MG, Brasil \\ ${ }^{3}$ Universidade do Estado do Mato Grosso, Nova Xavantina, MT, Brasil \\ ${ }^{4}$ Embrapa Café, Brasília, DF, Brasil \\ Corresponding author: A.C.S. Clemente \\ E-mail: alineagrolavras@gmail.com
}

Genet. Mol. Res. 14 (2): 4703-4715 (2015)

Received October 29, 2014

Accepted January 13, 2015

Published May 11, 2015

DOI http://dx.doi.org/10.4238/2015.May.11.3

\begin{abstract}
Seed germination and dormancy are complex phenomena that are controlled by many genes and environmental factors. Such genes are indicated by phytohormones that interact with each other, and may cause dormancy or promote seed germination. The objective of this study was to investigate gene expression associated with the biosynthetic pathways of abscisic acid (ABA), gibberellic acid (GA), and ethylene (ET) in dormant and germinated lettuce seeds. The expressions of $L s N C E D, L S G A 3 o x l$, and $A C O-B$ were evaluated in germinating and dormant seeds from the cultivars Everglades, Babá de Verão, Verônica, Salinas, Colorado, and Regina 71. The expressions of $L S N C E D$, $L S G A 3 O x 1$, and $A C O-B$ were related to the biosynthesis
\end{abstract}


of $\mathrm{ABA}, \mathrm{GA}$, and $\mathrm{ET}$, respectively; therefore, the presence of these substances depends on genotype. $L S N C E D$ expression only occurred in dormant seeds, and was connected to dormancy. LsGA3oxlexpression only occurred in germinated seeds, and was connected to germination. The $A C O-B$ gene was involved in ET biosynthesis, and was expressed differently in germinated and dormant seeds, depending on the genotype, indicating different functions for different characteristics. Furthermore, sensitivity to phytohormones appeared to be more important than the expression levels of $L S N C E D, L S G A 3 o x 1$, or $A C O-B$.

Key words: Lactuca sativa; Dormancy; Genetic analysis

\section{INTRODUCTION}

Lettuce (Lactuca sativa L.) is a species of great economic importance in Brazil and worldwide, and the use of high performance seeds is essential for successful growing. However, lettuce seeds are problematic in terms of physiological quality and have a high sensitivity to environmental conditions, and these factors hinder the rapid emergence and uniformity of a stand (Kozarewa et al., 2006; Contreras et al., 2008, 2009a; Hayashi et al., 2008).

The seed germination period is associated with the presence or absence of dormancy, which is the temporary incapacity of a viable and intact seed that germinates under favorable conditions. Dormancy may be stimulated by a variety of endogenous and environmental factors, as a combination of them, or even as competition between them (Hilhorst, 2007; Finkelstein et al., 2008).

Genetic studies in several species have identified dozens of genes that affect the imposition of, or freedom from, dormancy, and the ability of seeds to germinate soon after maturity. Many of these genes are linked to plant hormones, including gibberellic acid (GA), abscisic acid (ABA), ethylene (ET), cytokinins, brassinosteroids, and auxin (Nambara et al., 2000; Kucera et al., 2005; Achard et al., 2006; Seo et al., 2006; Feurtado and Kermode, 2007; Argyris et al., 2008; Linkies and Leubner-Metzger, 2012), as well as sugars (Dekkers et al., 2008), light (Sawada et al., 2008; Contreras et al., 2009b; Oh et al., 2009), temperature (Toh et al., 2008; Contreras et al., 2009a; Schwember and Bradford, 2010) and other regulating factors, which, depending on conditions, will determine whether a seed will germinate or lie dormant.

Most studies have found that levels of ABA and GA, as the main regulators of the state of dormancy, and the internal balance of these plant hormones, are what determine the beginning, continuity, and end of dormancy (Baskin and Baskin, 2004). In addition, ET also appears to be involved in breaking dormancy in lettuce seeds when they are at high temperatures (Kozarewa et al., 2006).

Transcriptome analyses in Arabidopsis and Nicotiana plumbaginifolia seeds have revealed that the genes AtNCED and AtGA3Ox are associated with the biosynthesis of GA and $\mathrm{ABA}$, and are associated with the imposition of, and freedom from, dormancy; an accumulation of ABA induces the imposition of dormancy, and an accumulation of GA promotes the end of dormancy and the initiation of germination (Bove et al., 2005; Cadman et al., 2006; Finch-Savage et al., 2007). AtNCED codifies 9-cis-epoxycarotenoid dioxygenase, an enzyme that is involved in the last stage of ABA biosynthesis, and AtGA3ox, which codifies the enzyme GA $3 \beta$-hydroxylase and is responsible for the conversion of GA12 into active GA in the cytosol (Toh et al., 2008). 
The levels of ABA and GA in seeds are what determine dormancy or the capacity for germination; however, the biosynthesis of these plant hormones may be affected by the presence of ET. Physiological studies indicate a role of ET in the promotion of germination, in which the presence of ET may negatively regulate the biosynthesis of ABA, thereby diminishing the degree of dormancy of the seeds. ET may also neutralize the responses of ABA and avoid dormancy, even if a reduction of ABA in the seed does not occur (Linkies et al., 2009). For this reason, the conversion of 1-aminocyclopropane-1-carboxylic acid (ACC) to ET via ACC oxidase (ACO) is necessary, and is a fundamental stage in the regulation of ET biosynthesis in seeds. The interaction between ABA and ET appears to occur at various levels, and is dependent on the tissue studied and on the process that is occurring (Ghassemian et al., 2000; Matilla and Matilla-Vázquez, 2008).

Studies have shown that there is an interaction and a synergy between ET and GA, and, depending on the development stage and the environmental conditions, the presence of one hormone may increase the responses of the other (Vriezen et al., 2004; De Grauwe et al., 2008). In addition, Iglesias-Fernández and Matilla (2010) found that the presence of GA during the initial stages of germination induces ET biosynthesis in Sisymbrium officinale L. seeds.

Since seed germination and dormancy are regulated by a complex network of interactions between hormones, studies involving the expression analyses of genes involved in the biosynthesis of these plant hormones are of great importance, for a better understanding of the genetic factors involved in the regulation of the germination and dormancy processes. Therefore, the aim of this study was to analyze the expression levels of the genes $L s N C E D$, $L s G A 3 O x 1$, and $A C O-B$, which are related to the biosynthesis of ABA, GA, and ET, respectively, in dormant and germinated lettuce seeds.

\section{MATERIAL AND METHODS}

The study was conducted at the Central Seed Laboratory, Department of Agriculture, Universidade Federal de Lavras. Seeds from the following cultivars were used: Everglades (thermotolerant), Babá de Verão (thermotolerant), Verônica (thermotolerant), Salinas (thermosensitive), Colorado (thermosensitive), and Regina 71 (thermotolerant), which were grown in the winter of 2011 and picked at harvest. Seeds were placed on two sheets of germibox paper that had been soaked in distilled water with a quantity equivalent to 2.5 times the weight of the paper, in gerbox-type acrylic boxes. The seeds were then incubated at three different temperatures $\left(20^{\circ}, 30^{\circ}\right.$, or $\left.35^{\circ} \mathrm{C}\right)$, and seeds with roots emerging were collected and stored at $-80^{\circ} \mathrm{C}$. Seven days after the initiation of soaking the dormant seeds were collected.

\section{Germination test}

A germination test was performed with four replications of 50 seeds distributed on two sheets of germibox paper, which had been moistened with distilled water with a quantity equivalent to 2.5 times the weight of the paper, in gerbox-type acrylic boxes. The boxes containing the seeds were maintained in a BOD (Biological oxygen demand) chamber at temperatures of $20^{\circ}, 30^{\circ}$, or $35^{\circ} \mathrm{C}$, and evaluations were performed after four and seven days of incubation (Brasil, 2009). The results are expressed as the percentage of normal seedlings. 


\section{Genes evaluated}

The genes related to the biosynthesis of $\mathrm{ABA}, \mathrm{GA}$, and $\mathrm{ET}$ chosen for the expression analysis using a quantitative reverse transcription polymerase chain reaction (qRT-PCR) were $L s N C E D, L S G A 3 O x 1$, and $A C O-B$. The genes $P P 2 A$ and $U B C 21$ were used as reference genes. The gene products and initiating sequences are presented in Table 1.

Table 1. Sequences of the oligonucleotides synthesized specifically for amplifying the genes connected with the biosynthesis of abscisic acid, gibberellic acid, ethylene, and reference genes.

\begin{tabular}{|c|c|c|}
\hline Gene & Gene product & Sequence \\
\hline LsNCED4 & Lactuca sativa dioxygenase 9-cis-epoxycarotenoide 4 & $\begin{array}{l}\text { F: TGATCCAGCGGTTCAGCTAA } \\
\text { R: TCACCAATTACCTCCAGACCAT }\end{array}$ \\
\hline LsGA3oxl & L. sativa gibberellin $3 \beta$-hydroxylase 1 & $\begin{array}{l}\text { F: GGTGACCTCCTCCACATATTATCC } \\
\text { R: TGTTGGGTTCGGTTCACCAT }\end{array}$ \\
\hline$A C O-B$ & ACC oxidase & $\begin{array}{l}\text { F: AGCGGTCTTCAGCTTCTCAAAG } \\
\text { R: CGAGATTGATGACGATGGAATG }\end{array}$ \\
\hline $\mathrm{PP}_{2} \mathrm{~A}$ & Protein phosphatase 2 & $\begin{array}{l}\text { F: TTGACGGAATCGGAGGTAAAA } \\
\text { R: CCGGCTGCACATTCCATT }\end{array}$ \\
\hline$U B C_{21}$ & Ubiquitin ligase & $\begin{array}{l}\text { F: TCTTAGATCACCGTCCCATCGT } \\
\text { R: TCTGAGATTGTCCGAGGATATGAG }\end{array}$ \\
\hline
\end{tabular}

\section{Extraction of total RNA}

RNA extraction was performed using the Phenol/SDS protocol. A total of $100 \mathrm{mg}$ of seeds were macerated in liquid nitrogen and transferred to microtubes, together with 0.5 $\mathrm{mL}$ of extraction buffer (0.18 M Tris, 0.09 M LiCl, $4.5 \mathrm{mM}$ EDTA, 1\% SDS, $\mathrm{pH}$ 8.2), 1\% $\beta$-mercaptoethanol, $50 \mu \mathrm{L} 3 \mathrm{M}$ sodium acetate, $\mathrm{pH} 4.0$, and $0.5 \mathrm{~mL}$ of a phenol: chloroform (5:1) solution. These were then homogenized in a vortex for $2 \mathrm{~min}$ and centrifuged for $20 \mathrm{~min}$ at $4{ }^{\circ} \mathrm{C}$ and $10,000 \mathrm{~g}$. After centrifuging, the supernatant was collected and transferred to a new tube, to which $0.5 \mathrm{~mL}$ of a phenol:chloroform:isoamyl alcohol solution $(25: 24: 1)$ was added. This was then centrifuged for $20 \mathrm{~min}$ at $4^{\circ} \mathrm{C}$ and $10,000 \mathrm{~g}$. The supernatant was again collected and transferred to a new tube, and a volume of chloroform equal to the volume of the supernatant collected was added. The samples were then centrifuged for $5 \mathrm{~min}$ at $4^{\circ} \mathrm{C}$ and $10,000 \mathrm{~g}$, and the supernatant obtained was transferred to another $1.5-\mathrm{mL}$ tube, to which was added 0.5 $\mathrm{mL} 8 \mathrm{M} \mathrm{LiCl}$ of the final volume of the supernatant; this was then incubated for $1 \mathrm{~h}$ at $-20^{\circ} \mathrm{C}$ for the precipitation of the RNA. It was then centrifuged for $30 \mathrm{~min}$ at $4^{\circ} \mathrm{C}$ and $10,000 \mathrm{~g}$. The supernatant was discarded and $1000 \mu \mathrm{L}$ of $80 \%$ ethanol was added to the pellet, which was centrifuged for $5 \mathrm{~min}$ at $4^{\circ} \mathrm{C}$ and $10,000 \mathrm{~g}$. After centrifuging, the supernatant was discarded and the RNA was resuspended in $20 \mu \mathrm{L}$ of ultrapure water treated with diethyl pyrocarbonate (DEPC), and autoclaved. The samples were stored at $-20^{\circ} \mathrm{C}$.

For an evaluation of the integrity of the samples extracted, the RNA was subjected to electrophoresis on $1 \%$ agarose gel $(\mathrm{m} / \mathrm{v})$ stained with ethidium bromide $(0.5 \mu \mathrm{g} / \mathrm{mL})$. This was then viewed under ultraviolet light, and the image was captured using an EDAS 290 (Kodak ${ }^{\circledR}$ ) photo documentation device. The samples were quantified in a spectrophotometer (Nanodrop ${ }^{\circledR}$ Spectrophotometer ND-1000) using the wavelengths 260 and $280 \mathrm{~nm}$, observing the 260/280 ratios. Samples with values that ranged from 1.8 to 2.1 were considered to be of high quality. All of the solutions used for the procedures described were prepared with water free of 
RNases, were treated with $0.01 \%$ DEPC, and, in addition, the plastic and glassware were also treated to deactivate RNases.

\section{Treatment with DNase and synthesis of cDNA}

All of the samples were treated with Ambion ${ }^{\circledR}$ DNase I DNA-free ${ }^{\mathrm{TM}}$ for the purpose of eliminating contamination by DNA. Therefore, $10 \mu \mathrm{g}$ total RNA, $1 \mu \mathrm{L}$ DNAse I, and $10 \mu \mathrm{L}$ DNase 10X buffer were added, with water treated with DEPC completing the reaction volume to $100 \mu \mathrm{L}$. The samples were then incubated at $37^{\circ} \mathrm{C}$ for $30 \mathrm{~min}$. Subsequently, $10 \mu \mathrm{L} 2 \mathrm{M}$ potassium acetate was added and the tubes were incubated in ice for $15 \mathrm{~min}$, centrifuged for $10 \mathrm{~min}$, and the supernatant was transferred to a new tube. Three-times its volume of $100 \%$ ethanol was added to the supernatant, and this was incubated at $-80^{\circ} \mathrm{C}$ for $2 \mathrm{~h}$ and centrifuged for $30 \mathrm{~min}$ at $4^{\circ} \mathrm{C}$ and $14,000 \mathrm{rpm}$. The supernatant was discarded and $400 \mu \mathrm{L} 70 \%$ ethanol was added to the pellet, which was slightly agitated to release it. This was centrifuged for 10 min at $4^{\circ} \mathrm{C}$ and $14,000 \mathrm{rpm}$, and the supernatant was discarded and the tubes were left open to dry. The RNA was then resuspended in $20 \mu \mathrm{L}$ DEPC water.

To confirm the purity of the RNA, a conventional PCR was performed using primers with endogenous control. The samples that did not show amplification after the PCR were considered to be free of DNA.

cDNA synthesis was conducted using a High-Capacity cDNA Reverse Transcription Kit (Applied Biosystems). First, the RNA was prepared at a concentration of $1 \mu \mathrm{g}$ in a final volume of $10 \mu \mathrm{L}$. After this stage, a mix was prepared containing $2 \mu \mathrm{L} 10 \mathrm{X}$ buffer of the enzyme, $2 \mu \mathrm{L}$ 10X RT random primers, $0.8 \mu \mathrm{L}$ dNTP mix $(100 \mathrm{mM}), 1 \mu \mathrm{L}$ MultiScribe $^{\mathrm{TM}}$ Reverse Transcriptase, and water, for a final volume of $10 \mu \mathrm{L} /$ sample. For each solution prepared of $10 \mu \mathrm{L}$ of RNA at $1 \mu \mathrm{g}, 10 \mu \mathrm{L}$ of this mix was added. The tubes were placed in a MultiGene ${ }^{\mathrm{TM}}$ Gradient thermal cycler (Labnet, NJ, USA) programmed with three stages: $10 \mathrm{~min}$ at $25^{\circ} \mathrm{C}$ for annealing the primers, $2 \mathrm{~h}$ at $37^{\circ} \mathrm{C}$ for enzyme action, and $5 \mathrm{~min}$ at $85^{\circ} \mathrm{C}$ to deactivate them. The samples were stored in a freezer at $-20^{\circ} \mathrm{C}$.

\section{qRT-PCR}

We used an ABI Prism ${ }^{\circledR} 7500$ Real-Time PCR (Applied Biosystems) for qRT-PCR using a SYBR ${ }^{\circledR}$ Green detection system, and cDNA was obtained from RNA extracted from germinated and dormant seeds from the different cultivars. The thermal conditions of the reaction were $2 \mathrm{~min}$ at $50^{\circ} \mathrm{C}, 10 \mathrm{~min}$ at $95^{\circ} \mathrm{C}$, followed by 40 cycles of $15 \mathrm{~s}$ at $95^{\circ} \mathrm{C}$ and $1 \mathrm{~min}$ at $60^{\circ} \mathrm{C}$, and finalizing with $15 \mathrm{~s}$ at $95^{\circ} \mathrm{C}$. The data were collected and stored in the 7500 Fast Software (Version 2.1). For each reaction, the following were used: $1.0 \mu \mathrm{L} \mathrm{cDNA}, 0.2 \mu \mathrm{L}$ of each primer, and 5.0 $\mu \mathrm{L}$ Master Mix SYBR ${ }^{\circledR}$ Green UDG with ROX (Invitrogen), for a final volume of $10 \mu \mathrm{L} / \mathrm{sample}$. Negative controls and melting curves were included in all of the analyses. The qRT-PCRs, for each gene in the study, were conducted with the different cDNAs obtained from each sample, with three technical replicates for each one, and the results were normalized using the threshold cycles (TCs) obtained by the expressions of the protein phosphatase 2 (PP2A) and ubiquitin ligase (UBC21) reference genes (Argyris et al., 2008).

The TC was defined as the number of cycles in which the fluorescence generated within a reaction crossed the baseline (threshold); the comparative TC method was used. 
As one of the necessary requirements for using this method, a validation experiment was performed to show the efficiencies of the amplifications of the target and reference genes. For this reason, standard curves were made for the genes under study in the following dilutions: $1: 5,1: 25,1: 125,1: 625$, and $1: 3125$. This procedure also determined the dilution of cDNA that was used in each reaction, which was 1:5. The concentration of each primer was $1.5 \mu \mathrm{M}$.

To calculate the gene expression, each sample was first normalized with the endogenous controls, protein phosphatase 2 and ubiquitin ligase, and relative quantification was obtained using the equation in Figure 1. The threshold was defined automatically.

\section{$\Delta \mathbf{C t}=\mathbf{C t}_{(\mathrm{TG})}-\mathbf{C t}_{(\mathrm{RGM})}$ $\Delta \Delta \mathbf{C t}=\Delta \mathbf{C t}-\Delta \mathbf{C t}$ (Control) Ration $=2^{-\Delta \Delta C t}$ \\ Target genes (TG) \\ Reference gene mean (RGM)}

Figure 1. Equation to calculate the relative quantification.

\section{Data analysis}

The data are presented as accumulated percentage curves of germination and dormancy for each treatment, using Sigma Plot 11.0. Standard deviations are presented in the form of bars to facilitate the interpretation of the data, and relative expression data are presented in the form of bar graphs. The results were analyzed in a comparative manner, with the sample that exhibited the lowest expression for each gene used as a calibrator.

\section{RESULTS}

The data are presented in Figure 2. The influence of temperature can be observed on the levels of dormancy. For all of the cultivars, maximum germination was observed when the seeds were subjected to a temperature of $20^{\circ} \mathrm{C}$. In the case of the Everglades cultivar, a germination level of approximately $95 \%$ of normal seedlings was observed when the seeds were soaked at $20^{\circ} \mathrm{C}$. At $30^{\circ} \mathrm{C}$, germination probability decreased to $60 \%$, with dormancy in $30 \%$ of the seeds. Dormancy became more evident when the seeds were exposed to $35^{\circ} \mathrm{C}$, which affected more than $70 \%$ of the seeds; germination was reduced to $20 \%$ under these high temperature conditions.

In the Colorado cultivar, the germination level was almost $80 \%$ at $20^{\circ} \mathrm{C}$, and there were few dormant seeds $(10 \%)$. This result was inverted when the seeds were subjected to $30^{\circ} \mathrm{C}$, with a greater percentage of dormant seeds (55\%) than normal seedlings $(30 \%)$, and an increase in dormancy at $35^{\circ} \mathrm{C}$, reaching values of almost $90 \%$ dormant seeds and an absence of germination.

Performance of the Babá de Verão cultivar was similar to that of the Verônica cultivar, with germination levels near $85 \%$ and low levels of dormancy $(10 \%)$ at $20^{\circ} \mathrm{C}$. The trend toward greater dormancy followed an increase in temperature; $60 \%$ of the seeds were dormant and $35 \%$ had germinated at $30^{\circ} \mathrm{C}$, and higher indices of dormancy were observed at $35^{\circ} \mathrm{C}$, 
with $80 \%$ dormancy in the Babá de Verão cultivar and 95\% dormancy in the Verônica cultivar. The results from the Salinas cultivar were similar, with a maximum germination level of $90 \%$ at $20^{\circ} \mathrm{C}$ and manifestations of dormancy at $30^{\circ} \mathrm{C}$, with $50 \%$ of the seeds being dormant and $30 \%$ germinating. At $35^{\circ} \mathrm{C}$, dormancy appeared in more than $90 \%$ of the seeds of this cultivar.
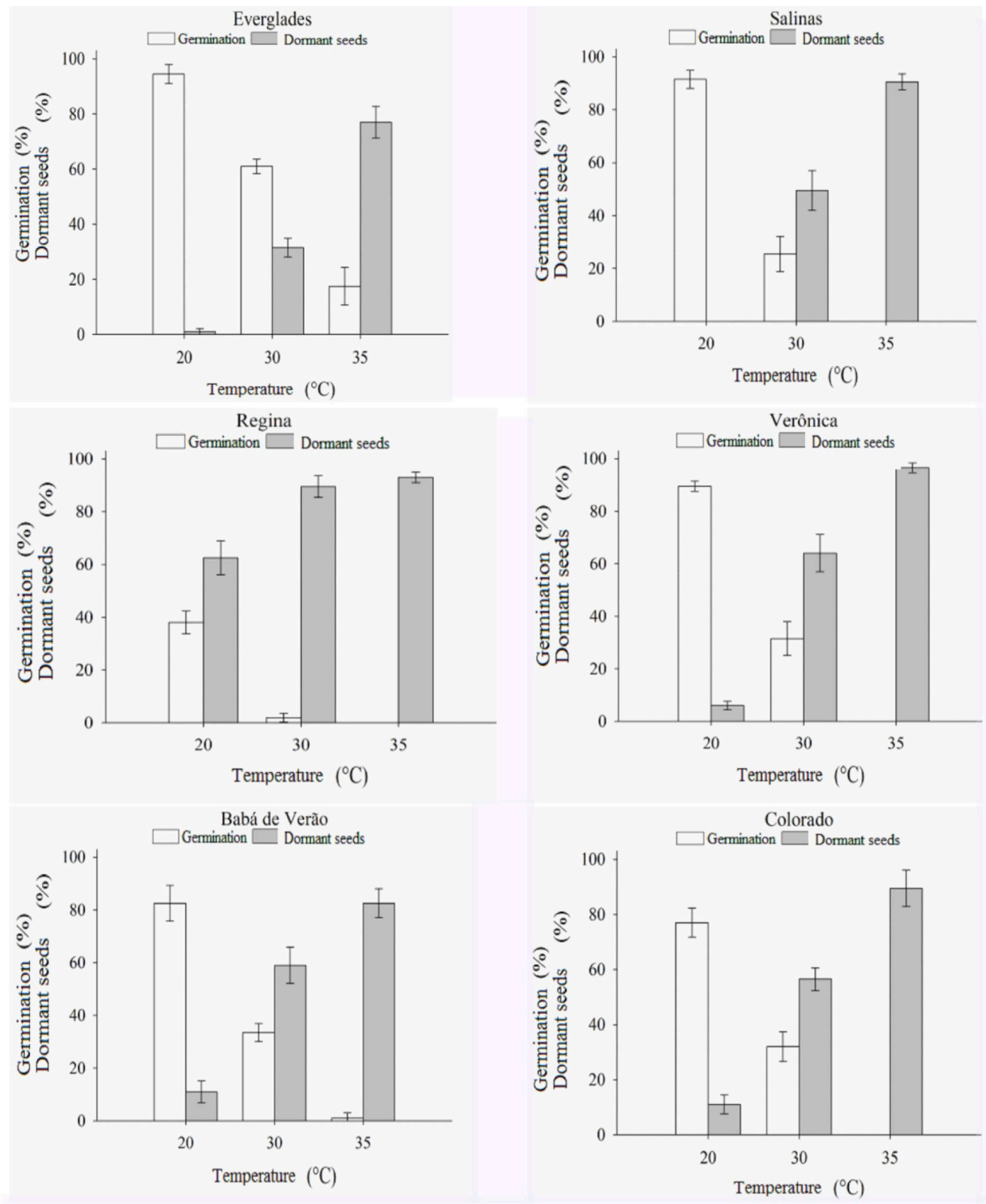

Figure 2. Percentage of germinated and dormant lettuce seeds of the cultivars Everglades, Colorado, Babá de Verão, Verônica, Salinas, and Regina at three temperatures $\left(20^{\circ}, 30^{\circ}\right.$, and $\left.35^{\circ} \mathrm{C}\right)$. 
A greater sensitivity to temperature was observed in the Regina cultivar, with manifestations of dormancy at high levels $(60 \%)$ at $20^{\circ} \mathrm{C}$ and a dormancy rate of above $80 \%$ when the seeds were exposed to $30^{\circ}$ or $35^{\circ} \mathrm{C}$.

The relative expression levels of the $L S N C E D$ gene in germinated and dormant lettuce seeds are shown in Figure 3. It can be seen that in germinated seeds there was no expression of the gene, while in dormant seeds the gene's expression levels differed between the cultivars.

LSNCED

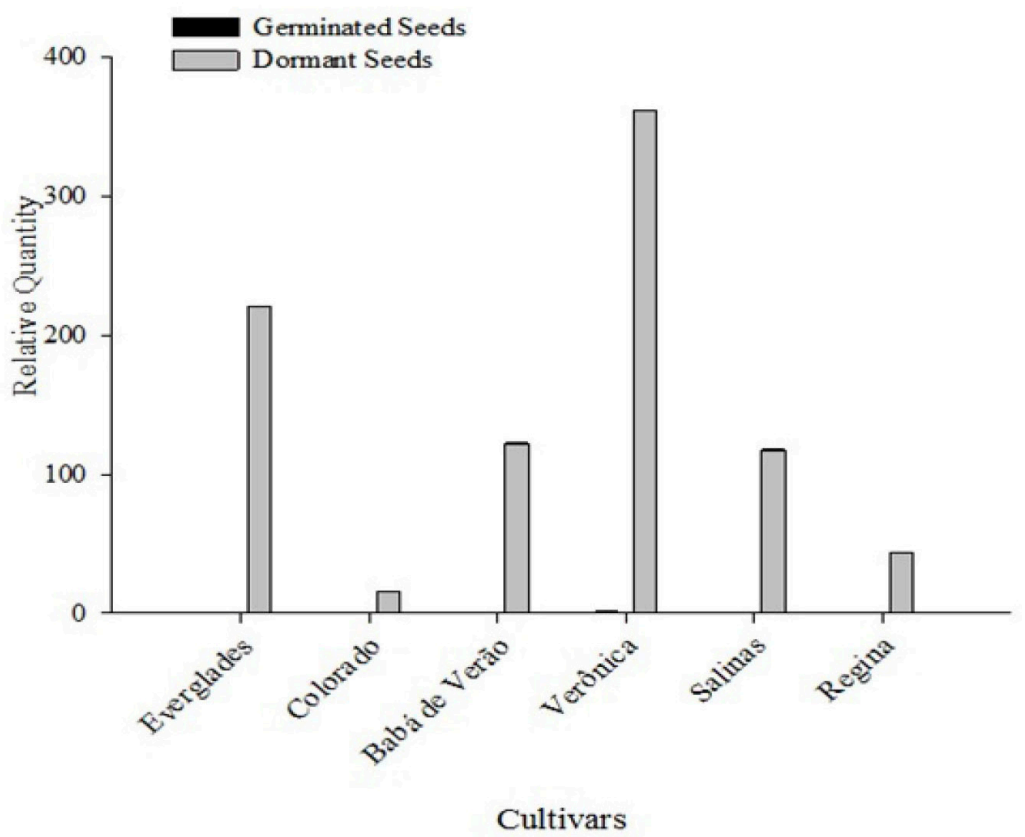

Figure 3. Profile of the relative expression of $L S N C E D$ determined by quantitative reverse transcription polymerase chain reaction in germinated and dormant lettuce seeds of the cultivars Everglades, Colorado, Babá de Verão, Verônica, Salinas, and Regina.

The greatest levels of expression of the $L s N C E D$ gene were observed in the Verônica cultivar, followed by the Everglades cultivar. In the Salinas and Babá de Verão cultivars, the expression levels of the gene were lower, with similar levels of expression observed in the two cultivars. Minimum indices of expression of $L S N C E D$ were observed in the Regina and Colorado cultivars.

The relative expression levels of the $L s G A 3 o x 1$ gene, which participates in the last stage of the biosynthesis of GA in germinated and dormant lettuce seeds, are shown in Figure 4. It can be seen that the expression of this gene occurred mainly in germinated seeds, and the levels of expression varied among the cultivars.

The highest expression levels of LsGA3oxl were observed in the germinated seeds of the Regina cultivar, which were twice as high as those of the Colorado and Verônica cultivars, which had similar levels of expression. It should be noted that there were low levels of LsGA3oxl expression in dormant seeds of the Colorado and Verônica cultivars, which were not observed in the others. 


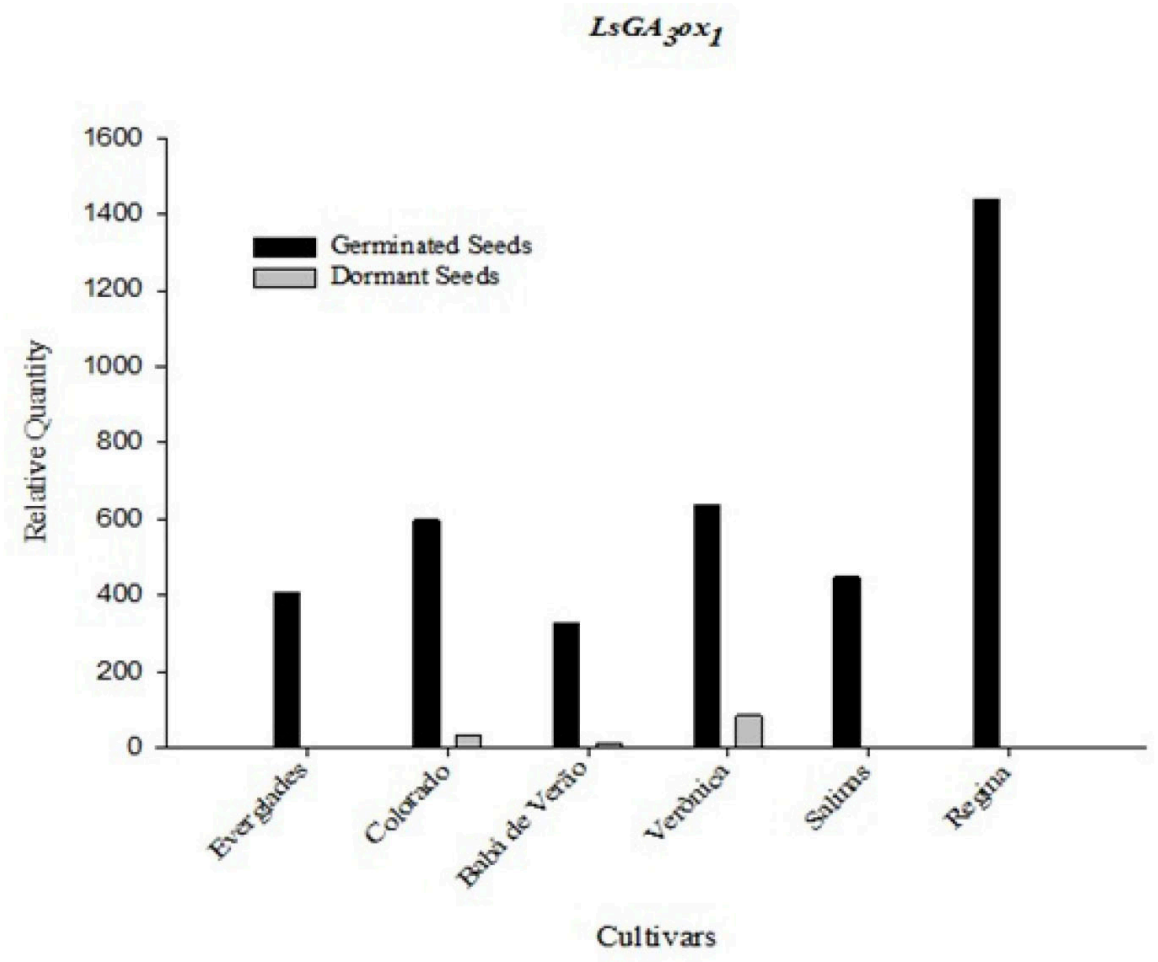

Figure 4. Profile of the relative expression of LsGA3oxl determined by quantitative reverse transcription polymerase chain reaction in germinated and dormant lettuce seeds of the cultivars Everglades, Colorado, Babá de Verão, Verônica, Salinas, and Regina.

In the Everglades and Salinas cultivars, the relative expression levels of LsGA3oxI were similar, or slightly higher, than its expression levels in the Babá de Verão cultivar, in which the lowest expression level in dormant seeds was observed.

The participation of ET during the germination of lettuce seeds was investigated by analyzing the expression of the $A C O-B$ gene, which is associated with the biosynthesis of ET (Figure 5). We found that the relative expression of $A C O-B$ differed between dormant and germinated seeds, depending on the cultivar analyzed.

In the Everglades and Colorado cultivars, the relative expression of $A C O-B$ was similar between the cultivars, in dormant and germinated seeds. Nevertheless, in the Babá de Verão cultivar, $A C O-B$ expression levels were twice as high in germinated seeds as they were in dormant seeds. An opposite result was seen in the Verônica cultivar, with a higher expression of $A C O-B$ observed in dormant than in germinated seeds.

The lowest relative expression level of $A C O-B$ was observed in the Salinas cultivar, with only small differences found between dormant and germinated seeds, but a higher expression level was seen in germinated seeds. In contrast, the highest relative expression level of $A C O-B$ was observed in germinated seeds of the Regina cultivar, which had expression levels that were approximately ten-times higher than those in dormant seeds. 
$A C O-B$

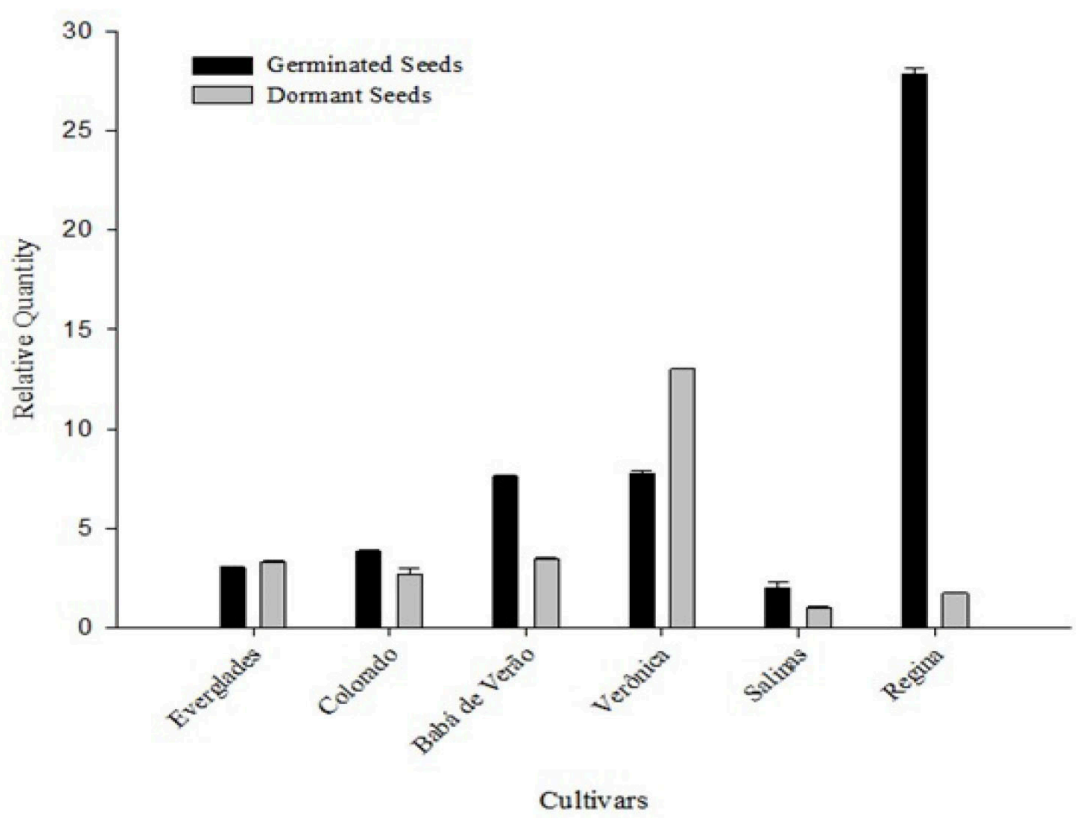

Figure 5. Profile of the relative expression of $A C O-B$ determined by quantitative reverse transcription polymerase chain reactionin germinated and dormant lettuce seeds of the cultivars Everglades, Colorado, Babá de Verão, Verônica, Salinas, and Regina.

\section{DISCUSSION}

The seeds of the Everglades cultivar, although considered to be thermotolerant (Nascimento and Pereira, 2007), exhibited dormancy when subjected to high temperatures $\left(30^{\circ}\right.$ and $35^{\circ} \mathrm{C}$ ), probably because the seeds used in this experiment were produced in the winter (Figure 2). According to Contreras et al. (2009a) and Kozarewa et al. (2006), better lettuce seed performance is obtained when production is conducted at high temperatures, thus reducing thermosensitivity. In this cultivar, significant expression of the LSNCED gene in dormant seeds (Figure 3), and a high expression of the $L s G A 30 x 1$ gene in germinated seeds was observed (Figure 4), which may be an indication of the involvement of ABA in the imposition of dormancy, just as GA is involved in inducing germination, as was observed by Argyris et al. (2008, 2011), Sawada et al. (2008), and Clemente et al (2013), also in lettuce seeds. It has also been reported that ET may have the opposite effects of ABA by overcoming dormancy, and in interaction with GA, induces germination (Linkies et al., 2009; Iglesias-Fernández and Matilla, 2010). In the present study, expression levels of the $A C O-B$ gene were similar in germinated and dormant seeds of the Everglades cultivar (Figure 5). Therefore, ET probably only induces germination in the presence of GA.

In the Colorado cultivar, dormancy was evident when the seeds were soaked at high temperatures $\left(30^{\circ}\right.$ and $35^{\circ} \mathrm{C}$ ) (Figure 2), demonstrating the effect of high temperature on the 
germination of lettuce seeds (Nascimento and Cantliffe, 2002). LsNCED expression was reduced in dormant seeds (Figure 3); nevertheless, considerable levels of LsGA3oxl expression were observed in germinated seeds (Figure 4), and $A C O-B$ expression was observed both in germinated and dormant seeds of this cultivar. According to Tarquis and Bradford (1992), there have been cases where a relationship has not been found between the ABA concentration, the sensitivity of the embryo to this growth regulator, and the ability of the seed to germinate early, indicating variation between lettuce genotypes in ABA sensitivity. Nevertheless, the participation of GA is essential for the germination of lettuce seeds, as reported by Argyris et al. (2008). The same authors, working with the Salinas and UC96US23 genotypes, found that $L s$ GA3oxl expression was high in the seeds soaked at $20^{\circ} \mathrm{C}$, but expression decreased when the temperature was increased to $35^{\circ} \mathrm{C}$, with a delay in germination occurring at that time (Argyris et al., 2011).

Seeds from the Babá de Verão and Verônica cultivars exhibited a high sensitivity to high temperatures $\left(30^{\circ}\right.$ and $35^{\circ} \mathrm{C}$ ) (Figure 2), although these cultivars are considered to be tolerant to heat in regard to flowering (Carvalho Filho et al., 2009; Villela et al., 2010). From these results, it can be seen that sensitivity to high temperatures at flowering may not be related to sensitivity to high temperatures at germination. Even when including germination, in which the results for these two cultivars were similar, the expression profiles of $L S N C E D$, $L s G A 3 o x 1$, and $A C O-B$ (Figures 3, 4, and 5) differed sharply between them. In the Verônica cultivar, dormant seed-LSNCED expression was approximately three times higher than that in the Babá de Verão cultivar. LsGA3oxl expression was slightly higher in the Verônica cultivar, and the expression of this gene was also detected in the dormant seeds of the cultivar. $A C O-B$ expression levels were similar in the seeds germinated of the two cultivars; in dormant seeds, there was greater expression of $A C O-B$ in the Verônica cultivar. This difference in sensitivity to different plant hormones was evident in the different genotypes in regard to germination and dormancy, as reported by Tarquis and Bradford (1992) for ABA.

In the Salinas cultivar, $L s N C E D$ expression levels in dormant seeds and LsGA3oxI expression levels in germinated seeds were high (Figures 3 and 4); however, $A C O-B$ expression was lower than in the other cultivars (Figure 5). This cultivar also proved to be sensitive to high temperatures, with increased levels of dormancy at $30^{\circ}$ and $35^{\circ} \mathrm{C} \mathrm{(Figure}$ 2). These results suggest that in the absence of ET there is a greater difficulty in overcoming dormancy in this cultivar, indicating that ET plays a relatively important role in freedom from dormancy and seed germination in the lettuce, as in many other species (Keçpczyński and Keçpczyńska, 1997).

The performance of the Regina 71 cultivar was poor when germination was analyzed at high temperatures (Figure 2), in spite of it being considered a plant tolerant to high temperatures in regard to flowering (Carvalho Filho, 2009). It seems that the Regina cultivar grown under low temperatures does not express its thermotolerance characteristics in seeds. The same result was obtained by Villela et al. (2010) in the Luiza cultivar, which is considered to be a plant resistant to heat: thermotolerance was only observed in seeds produced in the summer. In spite of the high dormancy index of the seeds of the Regina 71 cultivar, even at $20^{\circ} \mathrm{C}$ $L S N C E D$ expression was reduced (Figure 3), suggesting that the participation of ABA is not very significant in the imposition of dormancy in the seeds of this cultivar, whereas LsGA3oxl (Figure 4) and $A C O-B$ (Figure 5) exhibited a broad expression in germinated seeds. Tarquis and Bradford (1992) observed in lettuce seeds that genetic programming for germination has 
a greater effect than a reduction in the levels of endogenous ABA, as was found in this study, where the probable reduction of ABA was not sufficient to promote germination, suggesting that other factors may have a greater effect on germination.

\section{CONCLUSION}

Expression levels of the $L S N C E D, L S G A 3 o x 1$, and $A C O-B$ genes related to the biosynthesis of $\mathrm{ABA}, \mathrm{GA}$, and ET were dependent on genotype. LsNCED expression occurred exclusively in dormant seeds, and it is involved in the imposition of dormancy in lettuce seeds. $L s G A 3 o x 1$, which is associated with the biosynthesis of GA, exhibited its greatest expression in germinated lettuce seeds. $A C O-B$, which is involved in the biosynthesis of ET, was expressed differently, depending on different factors. Sensitivity to plant hormones appeared to be more important than the expression levels of $L s N C E D, L s G A 3 o x 1$, or $A C O-B$ in the cultivars.

\section{REFERENCES}

Achard P, Cheng H, De Grauwe L, Decat J, et al. (2006). Integration of plant responses to environmentally activated phytohormonal signals. Science 311: 91-94.

Argyris J, Dahal P, Hayashi E, Still DW, et al. (2008). Genetic variation for lettuce seed thermoinhibition is associated with temperature-sensitive expression of abscisic acid, gibberellin, and ethylene biosynthesis, metabolism, and response genes. Plant Physiol. 148: 926-947.

Argyris J, Truco M, Ochoa O, McHale L, et al. (2011). A gene encoding an abscisic acid biosynthetic enzyme LsNCED4 collocates with the high temperature germination locus Htg6.1 in lettuce (Lactuca sp.). Theor. Appl. Genet. 122: 95-108.

Baskin JM and Baskin CC (2004). A classification system for seed dormancy. Seed Sci. Res. 14: 1-16.

Bove J, Lucas P, Godin B, Ogé L, et al. (2005). Gene expression analysis by cDNA-AFLP highlights a set of new signaling networks and translational control during seed dormancy breaking in Nicotiana plumbaginifolia. Plant Mol. Biol. 57: 593-612.

Brasil (2009). Ministério da Agricultura, Pecuária e Abastecimento. Regras para Análise de Sementes. Mapa/ACS, Brasília.

Cadman CSC, Toorop PE, Hilhorst HWM and Finch-Savage WE (2006). Gene expression profiles of Arabidopsis Cvi seed during cycling through dormant and non-dormant states indicate a common underlying dormancy control mechanism. Plant J. 46: 805-822.

Carvalho Filho JLS, Gomes LAA, Biguzzi FA, Maluf WR, et al. (2009). F4 families of crispleaf lettuce with tolerance to early bolting and homozygous for resistance to Meloidogyne incognita race 1. Hortic. Bras. 27: 335-339.

Clemente ACS, Guimarães RM, Martins DC, Lima AA, et al. (2013). Gene expression associated with the biosynthetic pathway of abscisic acid, gibberellin and ethylene during lettuce seed development. Afr. J. Biotechnol. 12: 3676-3684.

Contreras S, Bennett MA, Metzger JD and Tay D (2008). Maternal light environment during seed development affects lettuce seed weight, germinability, and storability. HortScience 43: 845-852.

Contreras S, Bennett MA and Tay D (2009a). Temperature during seed development affects weight, germinability and storability of lettuce seeds. Seed Sci. Technol. 37: 398-412.

Contreras S, Bennett MA, Metzger JD, Tay D, et al. (2009b). Red to far-red ratio during seed development affects lettuce seed germinability and longevity. HortScience 44: 130-134.

De Grauwe L, Chaerle L, Dugardeyn J, Decat J, et al. (2008). Reduced gibberellin response affects ethylene biosynthesis and responsiveness in the Arabidopsis gai eto2-1 double mutant. New Phytol. 177: 128-141.

Dekkers BJW, Schuurmans JAMJ and Smeekens SCM (2008). Interaction between sugar and abscisic acid signalling during early seedling development in Arabidopsis. Plant Mol. Biol. 67: 151-167.

Feurtado JA and Kermode AR (2007). A merging of paths: abscisic acid and hormonal cross-talk in the control of seed dormancy maintenance and alleviation. In: Seed development, dormancy and germination (Bradford KJ and Nonogaki H, eds.) Blackwell, Oxford, 176-223.

Finch-Savage WE, Cadman CSC, Toorop TE, Lynn JR, et al. (2007). Seed dormancy release in Arabidopsis Cvi by dry after-ripening, low temperature, nitrate and light shows common quantitative patterns of gene expression directed by environmentally specific sensing. Plant J. 51: 60-78. 
Finkelstein R, Reeves W, Ariizumi T and Steber C (2008). Molecular aspects of seed dormancy. Annu. Rev. Plant Biol. 59: $387-415$.

Ghassemian M, Nambara E, Cutler S, Kawaide H, et al. (2000). Regulation of abscisic acid signaling by the ethylene response pathway in Arabidopsis. Plant Cell 12: 1117-1126.

Hayashi E, Aoyama N and Still DW (2008). Quantitative trait loci associated with lettuce seed germination under different temperature and light environments. Genome 51: 928-947.

Hilhorst HW (2007). Definitions and hypotheses of seed dormancy. In: Seed development, dormancy and germination Vol. 6 (Bradford K and Nonogaki H, eds.). Blackwell, Oxford, 50-67.

Iglesias-Fernández R and Matilla A (2010). Genes involved in ethylene and gibberellins metabolism are required for endosperm-limited germination of Sisymbrium officinale L. seeds. Planta 231: 653-664.

Kępczyński J and Kępczyńska E (1997). Ethylene in seed dormancy and germination. Physiol. Plant. 101: 720-726.

Kozarewa I, Cantliffe DJ, Nagata RT and Stoffella PJ (2006). High maturation temperature of lettuce seeds during development increased ethylene production and germination at elevated temperatures. J. Am. Soc. Hortic. Sci. 131: 564-570.

Kucera B, Cohn MA and Leubner-Metzger G (2005). Plant hormone interactions during seed dormancy release and germination. Seed Sci. Res. 15: 281-307.

Linkies A and Leubner-Metzger G (2012). Beyond gibberellins and abscisic acid: how ethylene and jasmonates control seed germination. Plant Cell Rep. 31: 253-270.

Linkies A, Müller K, Morris K, Tureckova V, et al. (2009). Ethylene interacts with abscisic acid to regulate endosperm rupture during germination: a comparative approach using Lepidium sativum and Arabidopsis thaliana. Plant Cell 21: 3803-3822.

Matilla AJ and Matilla-Vázquez MA (2008). Involvement of ethylene in seed physiology. Plant Sci. 175: 87-97.

Nambara E, Hayama R, Tsuchiya Y, Nishimura M, et al. (2000). The role of ABI3 and FUS3 loci in Arabidopsis thaliana on phase transition from late embryo development to germination. Dev. Biol. 220: 412-423.

Nascimento WM and Cantliffe DJ (2002). Germinação de sementes de alface sob altas temperaturas. Hort. Bras. 20: 103-106.

Nascimento WM and Pereira RS (2007). Testes para avaliação do potencial fisiológico de sementes de alface. Rev. Bras. Sementes 29: 175-179.

Oh E, Kang H, Yamaguchi S, Park J, et al. (2009). Genome-wide analysis of genes targeted by Phytochrome Interacting Factor 3-Like5 during seed germination in Arabidopsis. Plant Cell 21: 403-419.

Sawada Y, Aoki M, Nakaminami N, Mitsuhashi W, et al. (2008). Phytochrome- and gibberellin-mediated regulation of abscisic acid metabolism during germination of photoblastic lettuce seeds. Plant Physiol. 146: 1386-1396.

Schwember AR and Bradford KJ (2010). A genetic locus and gene expression patterns associated with the priming effect on lettuce seed germination at elevated temperatures. Plant Mol. Biol. 73: 105-118.

Seo M, Hanada A, Kuwahara A, Endo A, et al. (2006). Regulation of hormone metabolism in Arabidopsis seeds: phytochrome regulation of abscisic acid metabolism and abscisic acid regulation of gibberellin metabolism. Plant J. 48: 354-366.

Tarquis AM and Bradford KJ (1992). Prehydration and priming treatments that advance germination also increase the rate of deterioration of lettuce seed. J. Exp. Bot. 43: 307-317.

Toh S, Imamura A, Watanabe A, Nakabayashi K, et al. (2008). High temperature-induced abscisic acid biosynthesis and its role in the inhibition of gibberellin action in Arabidopsis seeds. Plant Physiol. 146: 1368-1385.

Villela RP, Souza RJ, Guimarães RM, Nascimento WM, et al. (2010). Produção e desempenho de sementes de cultivares de alface em duas épocas de plantio. Rev. Bras. Sementes 32: 158-169.

Vriezen WH, Achard P, Harberd NP and Van Der Straeten D (2004). Ethylene-mediated enhancement of apical hook formation in etiolated Arabidopsis thaliana seedlings is gibberellin dependent. Plant J. 37: 505-516. 